\title{
A 9M modell motivációs vizsgálata egy vidéki egyetem gazdasági szakos hallgatóinak körében
}

\author{
BALOGH PÉTER ${ }^{1}$ - NAGY RICHÁRD ${ }^{2}$
}

\begin{abstract}
ABSZTRAKT
A munkavállalók motiváltságának fenntartása kulcsfontosságú tényező. A vállalatoknak folyamatosan szem előtt kell tartaniuk az olyan rendszerek kidolgozását, melyek által ez a motiváció megmarad és minőségi munkát eredményez. Azonban a fiatal pályakezdók munkaerőpiacra történő belépése kihívást jelent az emberi eröforrás menedzsmentnek. A 9M modell összefoglalja a motiváció kiváltó okainak minden aspektusát, egy olyan kombinált motivációs rendszert nyújtva a vállalatok számára, ami elősegíti a kreatív és inspiráló munkahely kereteinek kiépítését. A kutatás célja, hogy értékelje a gazdasági szakokon tanuló hallgatók elvárásait az ideális első, illetve későbbi munkahelyükre vonatkozóan. A kérdőívet 121 hallgató töltötte ki. A szociodemográfiai jellemzők között a nem, lakhely és a végzettség szerepelt. Az adatbázis kiértékelése nem parametrikus eljárásokkal és fókomponens elemzéssel történt. Az eredmények alapján a női válaszadók előnyben részesítik a tiszta célmeghatározást és a visszajelzést, valamint a személyes kapcsolatokat. A magasabb végzettséggel rendelkező kitöltők nagyobb arányban gondolják fontosnak a szervezeti célokkal való azonosulást, mint az alapképzést teljesítők. Ugyanez a megállapítás igaz a megosztott értékekre és kultúrára. A fókomponens elemzés eredménye nem mutatott egyezést az eredeti modellel. A munka 9 szintje három eltérő csoportba lett sorolva az eredetihez képest.
\end{abstract}

KULCSSZAVAK: motiváció, 9M modell, hallgatók, munkavállalók, szervezeti kultúra

\section{ABSTRACT}

\section{Research on ambition conducted with economics students at a rural university using the 9M Motivational Model}

Being motivated is a key factor for every employee. On the one hand, companies are always working on the most efficient motivational system to ensure employees continue to perform high quality work. On the other hand, young workers entered the market which setup new obstacles for HRM. The 9M motivational model sums up all the aspects of reasons to be motivated for an employee. It gives companies a motivation-mix, which can be used to create an inspiring framework for employees in their everyday jobs. The aim of this research is to evaluate the expectations of economic students concerning their ideal first or next workplaces. The questionnaire was filled in by 121 students. The socio-demographic aspects were gender,

\footnotetext{
${ }^{1}$ Egyetemi tanár, Debreceni Egyetem Gazdaságtudományi Kar.

${ }^{2}$ Egyetemi hallgató, Debreceni Egyetem Gazdaságtudományi Kar.
} 


\section{TEMATIKUS TANULMÁNYOK - A munkaerőpiac gazdasági-társadalmi kérdései}

place of residence and levels between university studies. The database was evaluated using non-parametric procedures and principal component analysis. The results show that female respondents are more likely to favour clear instructions, feedback and interpersonal relations. Respondents with a higher degree are more likely to want to be one with the company's vision and mission than respondents during their bachelor studies. The same applies to the lever of culture and shared values. The result of the principal component analysis showed no similarity to the original model. The 9 levels of work were grouped into three different divisions than those seen in the original format.

KEYWORDS: motivation, 9M model, students, employees, organisational culture

\section{Bevezetés}

A motiváció, a motiváltság szerepe a szervezetek és az egyén mindennapjaiban is egyaránt alapvető fontossággal bírnak. A tanulmány a munkaerőpiacra történő belépés előtt álló gazdasági szakos hallgatók preferenciáit vizsgálta egy primer, önálló szerkesztésű kérdőíves megkérdezés által. Általánosságban megállapítható, hogy a munkahely választási preferenciáknál már nem a fizetés mértéke áll az első helyen, hanem egyéb tényezők - mint például a karrierlehetőség, gyakori visszajelzések - is befolyásolják az első vagy következő munkahely kiválasztásában a fiatal munkavállalókat. A francia 9M motivációs modell ezen tényezők együtteséből próbálja megalkotni azt a motivációs mixet, amely a szervezet számára kíván támpontokat nyújtani a leghatékonyabb juttatási csomag összeállításában. A modell használatával felmérhetővé válnak az egyes munkavállalók motivációjának háttértényezői, ezáltal téve könnyebbé az ösztönzési rendszer megtervezését. A magas teljesítmény tartóssá tételéhez elengedhetetlen a belső (intrinzik) motiváció megléte, amely túlmutat a vállalatok által leggyakrabban alkalmazott anyagi ösztönzőktől. A lojalitás eléréséhez fontos, hogy a vállalati és szervezeti célok és érdekek egyezzenek, a visszajelzés pedig mindkét oldalon legyen rendszeres és elérhető. A vállalat jövőjébe vetett hit megerősíti a munkavállalót abban, hogy részt akarjon venni a jövőbeli célok teljesítésében.

\section{Szakirodalmi áttekintés}

Az ember viselkedésének hátterében számos motívum meghúzódhat. Az emberi motiváció két alapvető típusa az eszközjellegű és az önjutalmazó motiváció. Előbbi esetben valamilyen külső tényező hatására alakul ki a motiváltság, ezzel szemben az önjutalmazó motiváció esetén a cselekvés motivációja a cselekvésben rejlő élvezet (Kadlót et al. 2014, Acar 2014). A szervezetek számára ez a két típus összhangja teremtheti meg azt a kettős motiváltságot, amely szükséges ahhoz, hogy a munkavállaló a tőle telhető legnagyobb mértékben járuljon hozzá a vállalat céljainak az eléré- 


\section{TEMATIKUS TANULMÁNYOK - A munkaerőpiac gazdasági-társadalmi kérdései}

séhez. A tudás hatékony hasznosításának fontos feltételei a motiváltság, a tudás hasznosításához szükséges készségek megléte, az elfogadható jövedelem, a fejlődési lehetőségek illetve a megfelelő egyéb külső körülmények. Az egyénekben meg van a lehetőség arra, hogy képzetté váljanak, információkat tudjanak gyüjteni és ezek által a problémákat képesek legyenek megoldani. A tudás megszerzéséhez, hatékony módon történő felhasználásához és megfelelő hasznosításához elsősorban motiváltságra és megfelelő személyes kompetenciákra van szükség (Poór et al. 2012, OECD 2004). A kutatás alanyait képező Y-generációra jellemző az ambíció, a folyamatos, élethosszig tartó tanulás igénye és a magas fokú kreativitás megléte (Oláh - Fónai 2015). Az egyéniség, az individuum elismerése, a csoportmunka, csoporthoz való tartozás érzése, a fejlődési lehetőségek, továbbá az immateriális értékek is kiemelten fontosak a számukra (Weiler 2004). A munkaerőpiacra történő belépésük időpontja az intenzív önfejlesztés időszakába esik, álláskereséssel kapcsolatos ismereteik, elvárásaik és szokásaik eltérőek az előző generációétól. Ennek valószínűsíthető okai közé tartozik, hogy az egyetemi képzések nem csak egy szúk rétegnek érhetőek el, illetve az információforrások és információs csatornák többrétűsége (Szretykó 2012). Gergely (2016) és Kiss, Barizsné és Kun (2017) vizsgálata is alátámasztja, hogy sokan közülük olyan karrierre vágynak, amely biztosítja számukra a fejlődési lehetőséget. A9M motivációs modell ezeket az igényeket próbálja egy keretbe foglalni.

A modellt Mathe és szerzőtársai (2011) a Sodexoval együttmúködve alkotta meg. Három fő dimenziót állapított meg, amelyekbe 3-3-3 motiváltságra ható egységet helyezett el.

Az „Éljünk!” dimenzió szerint az emberek számára a munka az elsődleges forrás az alapvető szükségleteik közvetlen és közvetett kielégítéséhez és a jólét eléréséhez. Ide sorolja a „A munkakörnyezet”, a „Munka és szerződéses feltételek” és a „Munka és magánélet egyensúlya” itemeket.

A „Fejlődjünk!” dimenzió szerint az embernek természetéből fakadóan éreznie kell alkalmasságát, kompetensségét. Emiatt érdekes és jelentőségteljes munkára van szüksége. Ebbe a kategóriába tartozik a „Minőségi munka és fejlődés”, a „Megbecsülés és ösztönzés”, illetve a „Mérhető célok és visszajelzés” részegységek.

A „Teremtsünk kapcsolatokat” dimenzió kiemeli a munkahelyen történő kapcsolatteremtés, szocializáció fontosságát. Az emberek tudatosan törekszenek a munkatársakkal, felettesekkel, ügyfelekkel és magával a szervezettel történő kapcsolatfelvételre. A szervezettel történő azonosulás mértékét méri a „Misszió és jövőkép” elem, további egységek a „Megosztott értékek, kultúra” és a „Munkahelyi kapcsolatok”.

A modell a kilenc alegység közti kapcsolatokkal kívánja azt szemléltetni, hogy a motiváltság felépítése nem utasításra történik, hanem minden nap tenni kell érte.

Magyarországon egyedül Farkas és szerzőtársai (2012) végeztek hasonló kutatást a témában. Eredményeik szerint a modell releváns a hazai környezetben. Kutatásuk alapján a modell legmeghatározóbb egységei a munkavállalók számára a munka és szerződéses feltételek, a misszió és jövőkép illetve a munkahelyi környezet. 


\section{TEMATIKUS TANULMÁNYOK - A munkaerőpiac gazdasági-társadalmi kérdései}

\section{A kutatás anyaga és módszertana}

A kutatáshoz használt kérdőív elkészítése a 9M motivációs modellhez tartozó szakirodalom (Mathe et al. 2011) elemzésével történt. A kérdőív a modell keretein belül próbálja felmérni a Debreceni Egyetem Gazdaságtudományi Karának gazdasági és vidékfejlesztési agrármérnöki alapszakos és gazdasági agrármérnöki mesterszakos hallgatók jövőbeli munkahely kiválasztásának preferenciáit. Az alapszakos hallgatók fele és minden mesterszakos hallgató töltötte ki a kérdőívet. A megkérdezetteknek a kérdőíven szereplő állításokat egy 1-től 7-ig terjedő Likert-skálán kellett értékelniük, ahol az 1-es érték az egyáltalán nem ért egyet, a hetes érték pedig a teljes mértékben egyet ért az adott állítással.

Az adatelemzés IBM SPSS 23.0 statisztikai szoftverrel történt meg. A kapcsolatok vizsgálatához először az értékek eloszlásának normalitását vizsgáltuk meg. Ehhez az egymintás Kolmogorov-Smirnov tesztet alkalmaztunk (Kovács 2014). A teszt nullhipotézise szerint a minta normális eloszlású. A teszt szignifikancia értéke közel volt a nullához $(\mathrm{p}<0,001)$, tehát a minta nem normális eloszlással rendelkezik, ezért a nem paraméteres eljárásokat lehet csak alkalmazni a további elemzések során. A nem normális eloszlás miatt a kérdőív kérdései és a csoportképző ismérvek közötti vizsgálatokhoz Mann-Whitney és Kruskal-Wallis rangteszteket alkalmaztunk (Field 2013, Rice 2006).

A fókomponens-analízis (Principal Component Analysis) (Hámori 2016) egy többváltozós statisztikai eljárás, mely az adatredukciós módszerek közé sorolható, $\mathrm{s}$ a faktoranalízis egy speciális esetének tekinthető. Célja, hogy egy nagy adathalmaz dimenzióit lecsökkentse, miközben a jelenlévő varianciát a lehető legjobban megtartja. A főkomponensek száma kisebb vagy egyenlő az eredeti változók számával. A transzformáció olyan módon meghatározott, hogy az első főkomponens rendelkezik a lehető legnagyobb varianciával, minden utána következő komponens a fennmaradó legnagyobb varianciával fog rendelkezni (Hunyadi-Vita 2008).

A vizsgált sokaság szociodemográfiai jellemzőiről megállapítható, hogy a megkérdezett hallgatók közül 70 fő nő, 47 fó férfi, 4 fő nem válaszolt a kérdésre. A megkérdezett hallgatók 23\%-a lakik Debrecenben vagy a 10 km-es vonzáskörzetében, $32 \%$ a megyeszékhelyünktől 10-50 km-es, $45 \%$ pedig legalább 50 km-es távolságból utazik be a tanórákra. A vidékiek magas, 77\%-os részaránya tökéletesen jellemzi a szakképzés orientáltságát: a mezőgazdasággal kapcsolatos gazdasági, gazdálkodási, jogi tudásanyag átadását.

\section{Eredmények}

A következőkben a kutatás eredményeit kívánjuk ismertetni a csoportképző ismérvek bontásában, majd végül a főkomponens analízis eredményeinek bemutatásával. 
www. metszetek.unideb.hu

\section{TEMATIKUS TANULMÁNYOK - A munkaerőpiac gazdasági-társadalmi kérdései}

A csoportképző ismérv és az állítások közti kapcsolatokat vizsgálva kettő esetben mutatható ki állításon belüli szignifikáns eltérés, amelyet az 1. táblázat mutat be.

1. táblázat. A modell elemei és a nemek közötti kapcsolatok

\begin{tabular}{|l|l|c|c|c|c|}
\hline \multicolumn{2}{|c|}{ Megnevezések } & $\begin{array}{c}\text { Elemszám } \\
\text { (darab) }\end{array}$ & Rangátlag & $\begin{array}{c}\text { Átlagok } \\
\text { (pontszám) }\end{array}$ & $\begin{array}{c}\text { Medián } \\
\text { (pontszám) }\end{array}$ \\
\hline \multirow{3}{*}{ Mérhető célok } & Férfi & 47 & 48,30 & 5,08 & 5 \\
\cline { 2 - 6 } & Nő & 70 & $66,19 *$ & 5,68 & 6 \\
\cline { 2 - 6 } & Összesen & 117 & - & 5,44 & 6 \\
\hline \multirow{3}{*}{ Munkahelyi kapcsolatok } & Férfi & 47 & 49,34 & 6,00 & 6 \\
\cline { 2 - 6 } & Nő & 70 & $65,49^{*}$ & 6,46 & 7 \\
\cline { 2 - 6 } & Összesen & 117 & - & 6,27 & 6 \\
\hline
\end{tabular}

Mann Whitney rangteszt, ${ }^{*} \mathrm{p}<0,05$

Forrás: Saját szerkesztés, 2017

A sokaságra vonatkoztatva megállapítható, hogy a női válaszadók statisztikailag kimutatható mértékben gondolják számukra fontosabbnak a mérhető célok, a viszszacsatolási pont meglétét, mint a férfiak. A világos feltételrendszer meghatározása, a vállalati cél érdekében tett munkavállalói erőfeszítések értékelése a női kitöltők számára szignifikánsan fontosabbak. Továbbá, a munkahelyi kapcsolatok minősége a munkahelyi motiváció olyan központi eleme, amely nagy befolyással van a munkatárs hozzáállására illetve a munkában lelt örömének a meglelésére és fenntartására. A humán hierarchiában betöltött pozíció egy olyan tényező, amely a legtöbb munkahelyi stresszért a felelős (Buckingham - Coffman 1999).

A szignifikáns szinthez közel $(\mathrm{p}=0,076)$ mutatható ki eltérés a „Munka és szerződéses feltételek” elemnél. Ez az elem a fenti két kategóriához hasonlóan van felépítve, amely közel szignifikáns eltérést jelentett ebben az esetben is. A „Munka és szerződéses feltételek” tartalmazza többek között a munkaköri felelősséget, hatáskört - amelyekhez a célok kapcsolhatóak -, továbbá az erőfeszítésekért kapott fizetést a munkatársakhoz viszonyítva egyaránt, amely a humán hierarchia részét is képezi. Ebben a vizsgálati egységben is a női válaszadók nyilatkoztak úgy, hogy számukra meghatározóbb ez a munkahelyi feltétel.

A lakhely és a modell elemei közti szignifikáns kapcsolat csak egy esetben mutatható ki (2. táblázat). 
www. metszetek.unideb.hu

\section{TEMATIKUS TANULMÁNYOK - A munkaerőpiac gazdasági-társadalmi kérdései}

2. táblázat. A munka és magánélet egyensúlya és a lakhely közötti kapcsolat

\begin{tabular}{|l|l|c|c|c|c|}
\hline \multicolumn{2}{|c|}{ Megnevezések } & $\begin{array}{c}\text { Elemszám } \\
\text { (darab) }\end{array}$ & Rangátlag & $\begin{array}{c}\text { Átlagok } \\
\text { (pontszám) }\end{array}$ & $\begin{array}{c}\text { Medián } \\
\text { (pontszám) }\end{array}$ \\
\hline \multirow{2}{*}{$\begin{array}{l}\text { Munka és magánélet } \\
\text { egyensúlya }\end{array}$} & $\begin{array}{l}\text { Debrecen vagy 10 } \\
\text { km-es környezete }\end{array}$ & 28 & 28,14 & 5,68 & 6 \\
\cline { 2 - 6 } & $\begin{array}{l}\text { Debrecen 10-50 } \\
\text { km-es körzete }\end{array}$ & 39 & $38,21^{*}$ & 6,21 & 7 \\
\cline { 2 - 6 } & Összesen & 67 & - & 5,99 & 6 \\
\hline
\end{tabular}

Mann Whitney rangteszt, ${ }^{*} \mathrm{p}<0,05$

Forrás: Saját szerkesztés, 2017

A munka és a magánélet közti egyensúly megléte a megyeszékhelytől 10-50 kmre élők számára fontosabb, mint a Debrecenben vagy közvetlen vonzáskörzetében élők számára. Ennek egyik oka az lehet, hogy az ingázás időt von el a magánéletből, ezért nehezebb az összeegyeztetés. A tanulmányok előrehaladási foka és a modell egységei közötti jelentős kapcsolatokat az 1. melléklet szemlélteti.

A „Megosztott értékek” (vállalati kultúra, társadalmi felelősségvállalás) egységen belül megfigyelhető, hogy a mesterképzésen tanuló hallgatók számára az egységes kulturális közösségbe való tartozás magasabb prioritási értéket vesz fel, mint az alapképzést folytató kitöltők számára. Az évfolyamokat páronként csoportosítva Mann-Whitney teszttel megvizsgálva, a BSc. 1. évfolyam és a Mesterképzés között mutatható ki statisztikai $(\mathrm{p}<0,05)$ eltérés. Ennek oka lehet, hogy a mesterképzésen részt vevők már több munkatapasztalattal rendelkezhetnek, mint alsóbb éves társaik, ezáltal a munkahelyi közösségbe való tartozás minőségének a fontosságát már megtapasztalhatták. Továbbá differenciáló tényező lehet még az idősebbek érettebb gondolkodása és a képzés során tanult ismeretek alkalmazása.

A vállalati „Misszió és jövőkép”-pel (vállalati célokkal történő azonosulás) történő azonosulás fontossága is a tanulmányokban történő előrehaladással egyenes arányban növekszik. Ebben az esetben is az MSc-s hallgatók és az első évfolyamot végzők átlagértékei között mutatható ki szignifikáns különbség $(p<0,05)$. A mögöttes ok valószínűsíthetően hasonló a „Megosztott értékek” egységnél kifejtetthez, miszerint a vállalat céljaival, missziójával történő azonosulás azért fontosabb az MSc-s hallgatók számára, mert több munkatapasztalattal rendelkezhetnek, mint alsóbb évfolyamos társaik.

A „Munka és szerződéses feltételek” egységnél már nem fedezhető fel az évfolyamok adta átlagpontszámok közti arányos növekedés. A bemeneti és kimeneti évfolyamok hasonló átlagértékei ellenére, szignifikáns különbség a Mann-Whitney rangteszttel csak az alapképzés két vizsgált évfolyama közt mutatható ki $(p<0,05)$. További vizsgálatok tárgyát képezheti a különbség pontos okának feltárása, mert a 


\section{TEMATIKUS TANULMÁNYOK - A munkaerőpiac gazdasági-társadalmi kérdései}

vizsgált egységet több egyéb tényező is alkotja (pénzbeli juttatás, szociális juttatás, munkavállalói érdekképviselet, munkaköri leírás).

A 9M motivációs modell egységeinek főkomponens analízise során a struktúra (2. melléklet) teljes mértékben tükrözi az eredeti modell kilenc elemét, azonban a főkomponens analízis másképpen csoportosította a vizsgált sokaság válaszai alapján az alapmodell elemeit. A modell az összes variancia 58\%-át magyarázza 21\%-18\% és 18\%-os részegységekben. Három főkomponensre osztottuk az egységeket az eredeti modellhez hasonlóan, azonban a három dimenzió teljesen más egységekből épül fel. Az első dimenziót a „Munka és szerződéses feltételek” (eredetileg „Éljünk!” dimenzió), a „Munkahelyi kapcsolatok” („Teremtsünk kapcsolatokat!”) és a „Megbecsülés és ösztönzés” („Fejlődjünk!”) alkotja. A főkomponens analízissel megalkotott második és harmadik dimenzió elemeinél is megfigyelhető, hogy az alkotórészek az eredeti modell különböző dimenzióiból állnak össze. Ennek oka lehet az, hogy bár a vizsgált személyek nagy része munkatapasztalattal rendelkezett, de a kérdőívek kitöltésekor tanulói státuszban volt. Ez okozhatta az elméleti modellhez képest eltérő munkahellyel szembeni elvárásokat.

\section{5. Összefoglalás}

A motiváció meghatározó jelentőséggel van jelen minden szervezet életében. A 9M motivációs modell szerint kilenc fontos tényezője van a motivációnak, amelyek három nagy csoportra oszthatóak: „Éljünk!”, „Fejlődjünk!”, „Teremtsünk kapcsolatokat". A szerzők szerint ezen tényezők együttes kielégítése vezet a motiváltság kialakulásához.

A kutatás célja a Debreceni Egyetem Gazdaságtudományi Karának gazdasági és vidékfejlesztési agrármérnöki illetve gazdasági agrármérnök hallgatóinak motivációs vizsgálata a modell mentén. A felállított szoci-demográfiai csoportok közti különbségeket nem-parametrikus módszerekkel vizsgáltuk, illetve a modell 9 tényezőjének újracsoportosítására fókomponens elemzést alkalmaztunk.

A nemek esetén megállapítható, hogy a női kitöltők számára jelentősen fontosabb a mérhető célok és célkitúzések megléte, illetve a munkahelyi kapcsolatok minősége. A lakhelyek szerinti vizsgálat során a munka és magánélet kapcsolatánál mutatható ki eltérés. A Debrecentől legalább 10 km-es távolságban élők fontosabbnak tartják, hogy a munka és magánélet közti határok kevésbé mosódjanak el. Az évfolyamok közti adatelemzés során mutatható ki a legtöbb eltérés az egyes motiváló tényezők fontossága között. A mérhető célok, a visszacsatolás megléte a képzésben történő előrehaladással együtt válik egyre fontosabbá a hallgatók számára. A munka és szerződéses feltételek esetén $(\mathrm{p}<0,05)$ a szignifikáns különbség nem a képzési előrehaladással arányos. A BSc 1. és MSc 1 . évfolyamos hallgatók fontosabbnak tartják a munkaköri leírás és szerződéses feltételek pontosságát, tartamát és formáját. 


\section{TEMATIKUS TANULMÁNYOK - A munkaerőpiac gazdasági-társadalmi kérdései}

Ez valószínűsíthetően összefüggésben van azzal, hogy az alapszak első évfolyamos hallgatói nem feltétlenül rendelkeznek reális tudással az adott szakterületre jellemző munkakörrel vagy fizetési feltétellel. Harmadévre azonban reálisabban láthatják az adott területet, igényeik, preferenciáik változhatnak az eredeti elvárásokhoz képest. A modell 9 elemén főkomponens analízist futtattunk le annak érdekében, hogy megvizsgáljuk az adott sokaságban a komponensenkénti eloszlásait az itemeknek. Három főkomponens került kialakításra - a modell fő dimenzióihoz hasonlóan -, amely során a komponens mátrix értékeit felhasználva kerültek besorolásra a modell itemei. A vizsgált korosztály (egyetemi hallgatók) esetében az eredeti modelltől eltérő csoportosítások jöttek létre. Mind a három főkomponens elemeit az elméleti modell különböző dimenzióiból származó összetevői alkották. Ennek az lehet az oka, hogy bár a vizsgált személyek nagy része munkatapasztalattal rendelkezett, de a kérdőívek kitöltésekor tanulói státuszban volt. Ez okozhatta az eltérő munkahelylyel szembeni elvárásokat.

Következtetésként megállapítható, hogy a megfelelő ösztönző rendszer kialakítása a vállalatok számára egy kihívásokkal teli folyamat, mivel a leendő munkavállalókat hajtó motiváló erők meghatározása és egységként történő kategorizálása komplikált feladat, amelyhez nem elég egy központosított HRM szervezeti egység.

\section{Mellékletek}

1. melléklet. A modell elemei és a végzettség közötti kapcsolatok

\begin{tabular}{|l|l|c|c|c|c|}
\hline \multicolumn{2}{|c|}{ Megnevezések } & $\begin{array}{c}\text { Elemszám } \\
\text { (darab) }\end{array}$ & Rangátlag & $\begin{array}{c}\text { Átlagok } \\
\text { (pontszám) }\end{array}$ & $\begin{array}{c}\text { Medián } \\
\text { (pontszám) }\end{array}$ \\
\hline \multirow{4}{*}{$\begin{array}{l}\text { Megosztott } \\
\text { értékek }\end{array}$} & BSc 1. évfolyam & 62 & 53,75 & 5,04 & 5 \\
\cline { 2 - 6 } & BSc 3. évfolyam & 46 & 64,79 & 5,45 & 5 \\
\cline { 2 - 6 } & Mesterképzés & 13 & $82,15^{*}$ & 6 & 6 \\
\cline { 2 - 6 } & Összesen & 121 & - & 5,30 & 5 \\
\hline \multirow{4}{*}{$\begin{array}{l}\text { Misszió és } \\
\text { jövókép }\end{array}$} & BSc 1. évfolyam & 62 & 52,91 & 4,77 & 5 \\
\cline { 2 - 6 } & BSc 3. évfolyam & 46 & 67,71 & 5,35 & 5 \\
\cline { 2 - 6 } & Mesterképzés & 13 & $75,85^{*}$ & 5,62 & 6 \\
\cline { 2 - 6 } & Összesen & 121 & - & 5,08 & 5 \\
\hline \multirow{4}{*}{$\begin{array}{l}\text { Munka és } \\
\text { feltételek }\end{array}$} & BSc 1. évfolyam & 62 & 65,60 & 6,80 & 7 \\
\cline { 2 - 6 } & BSc 3. évfolyam & 46 & 53,89 & 6,63 & 7 \\
\cline { 2 - 6 } & Mesterképzés & 13 & $64,23^{*}$ & 6,84 & 7 \\
\cline { 2 - 6 } & Összesen & 121 & - & 6,74 & 7 \\
\hline
\end{tabular}

Kruskal-Wallis rangteszt, ${ }^{*} \mathrm{p}<0,05$

Forrás: Saját szerkesztés, 2017 
www. metszetek.unideb.hu

\section{TEMATIKUS TANULMÁNYOK - A munkaerőpiac gazdasági-társadalmi kérdései}

2. melléklet. A főkomponens elemzés eredménye

\begin{tabular}{|l|c|c|c|}
\hline \multirow{2}{*}{ A 9M motivációs modell egységei } & \multicolumn{3}{|c|}{ Főkomponensek } \\
\cline { 2 - 4 } & 1. dimenzió & 2. dimenzió & 3. dimenzió \\
\hline Munka és szerződéses feltételek & 0,732 & & \\
\hline Munkahelyi kapcsolatok & 0,702 & & \\
\hline Megbecsülés és ösztönzés & 0,681 & & \\
\hline Munka és magánélet kapcsolata & & 0,731 & \\
\hline Munkahelyi környezet & & 0,716 & \\
\hline Mérhető célok & & 0,425 & \\
\hline Misszió és jövőkép & & & 0,822 \\
\hline Megosztott értékek & & & 0,612 \\
\hline Minőségi munka és fejlődés & & & 0,563 \\
\hline
\end{tabular}

Módszer: Főkomponens analízis; Rotációs módszer: Varimax rotáció Kaiser Normalizációval Rotációk száma 8. KMO = 0,647; Bartlett teszt (Khi-négyzet érték) 186,989; P <0,001; Kommunalitások: 0,349-0,733; Magyarázott variancia: 58,084\%; $\mathrm{N}=121$.

Forrás: Saját szerkesztés, 2017

\section{Irodalom}

Acar, A. B. (2014): Do Intrinsic and Extrinsic Motivation Factors Differ for Generation $\mathrm{X}$ and Generation Y? International Journal of Business and Social Science. Vol. 5, No. 5, 12-20.

Buckingham, M. - Coffman, C. (1999): First, Break All the Rules. New York. Simon and Schuster.

Farkas, F. - Jarjabka, Á. - Lóránd, B. - Bálint, B. (2013): Munkahelyi motivációk Magyarországon 2013-ban. Vezetéstudomány XLIV. évf. 10. sz., 12-23.

Field, A. (2013): Discovering Statistics Using IBM SPSS Statistics. New York, SAGE Publications.

Gergely, É. (2016): Karriervizsgálatok egyetemisták körében. Közép-Európai Közlemények IX. évf., Vol 2., No. 33, 134-145.

Hámori, G. (2016): A magyarázóváltozók kezelésének egyes kérdései regressziós modellezés során. Statisztikai Szemle 94. évfolyam, 1. szám. https://www.ksh. hu/docs/hun/xftp/statszemle/2016_01_005.pdf; letöltés dátuma: 2017.05.04.

Hunyadi, L. - Vita, L. (2008): Statisztika I. Aula Kiadó, Budapest. 


\section{TEMATIKUS TANULMÁNYOK - A munkaerőpiac gazdasági-társadalmi kérdései}

Kadlót, N. - Kurkó, N. - Somoskői, D. - Szijjártó, A. - Takács, E. - Weninger, A. - Zabolai, E. M. (2014): Kreativitás \& Mobilitás - A magyar felsőoktatás mint országmárka. Nemzeti Közszolgálati és Tankönyv Kiadó Zrt., Budapest.

Kiss, Zs. - Barizsné, H. E. - Kun, A. I. (2017): A leendő munkavállalás hallgatói szemmel: egy a Debreceni Egyetem alapszakos hallgatói körében végzett felmérés eredményei. Taylor: Gazdálkodás- és szervezéstudományi folyóirat. A Virtuális Intézet Közép-Európa Kutatásáért Közleményei IX. évf. 1. sz. No. 27., 183-190.

Kovács, E. (2014): Többváltozós adatelemzés. Typotex Kiadó, Budapest.

Mathe, H. - Pavie, X. - O'Keffe, M. (2011): Valuing people to create value. Singapore, World Scientific Publishing Co. Pte. Ltd.

OECD (2004): Knowledge Management in the Learning Society. Paris, OECD Publishing.

Oláh, J. - Fónai, E. (2015): Piacképes-e az ifjúság? Taylor: Gazdálkodás- és szervezéstudományi folyóirat. A Virtuális Intézet Közép-Európa Kutatásáért Közleményei VII. évfolyam, Vol 1-2, No. 18-19., 294-301.

Poór, J. - Karoliny, M. - Berde, Cs. - Takács, S. (2012): Átalakuló emberi erőforrás menedzsment. Wolters Kluwer, Budapest.

Rice, J. A. (2006): Mathematical Statistics and Data Analysis. Boston, Cengage Learning.

Szretykó, Gy. (2012): Az Y generáció, a munkáltató vonzóvá tétele a munkaerőpiacon és a HR stratégia. Humánpolitikai Szemle Vol 23, No. 7-8., 3-12.

Weiler, A. (2004): Information-Seeking Behavior in Generation Y Students: Motivation, Critical Thinking, and Learning Theory. The Journal of Academic Librarianship, Vol 31, No. 1., 46-53. 